\title{
THE IMPACT OF MENTAL MAPPING ON PUPILS' ATTITUDES TO LEARNING Rebeka Štefánia Koleňáková ${ }^{1}$, Nina Kozárová ${ }^{2}$
}

\begin{abstract}
In education, it is essential to ensure that the relationship established between pupils and education or learning itself is positive. A teacher should help pupils while building their inner knowledge system and ensure that this process is conducted without coercion but with interest and a positive attitude.

The subject of the research are mental maps and their impact on attitudes of primary school pupils to "learning". In the research investigation, a questionnaire with 11 items was used and the respondents were primary school pupils who regularly work with mental maps in the educational process, and pupils who do not work with mental maps regularly. The results of the survey point out the disparities in attitudes to "learning". $85 \%$ of surveyed pupils who regularly use mental maps indicated that they learn faster and better, they also stated that learning in school is fun, whereas only 55\% of pupils in the second group who do not work with mental maps regularly share this opinion.

Based on creating a mental map, pupils become active participants in the educational process and create knowledge structures without repeated explanation. Pupils' activity using mental maps in the educational process seems to be the first efficient step towards better learning and a more positive attitude to this process.
\end{abstract}

UDC Classification: 37.01 , DOI: 10.12955/cbup.v7.1402

Keywords: mental maps, attitudes, learning, pupils, primary education.

\section{Introduction}

Contemporary education emphasises above all the learning content, teachers, educational goals, textbooks, but also educational strategies and teaching methods. Nowadays, the most criticized topic is the mediation of learning content in a pre-processed form. At the same time, the role of pupils in the educational process is in focus. In many cases, because of teaching led in this manner, pupils unfortunately do not have to think critically, assess information, interconnect it or find connections.

Every person is familiar with the term "learning". However, it should be stated that it does not seem to be an attractive or interesting term. Quite to the contrary, for many pupils it represents boredom, worries and a never-ending process.

It is important to consider the fact that there are many methods, ways and strategies in which pupils learn. Similarly, there are constantly new innovations in education-oriented at increasing the efficiency of the educational process, its facilitation, motivation of pupils for learning and their activation during the educational process. This innovation includes the method of creating and working with a mental map that helps with orientation in learning content, understanding of learning content, and represents an easier, more efficient and interesting way of learning. This means that it is necessary to consider pupils' attitudes and opinions about activities in progress during the educational process. We think that it is crucial that pupils are interested in education and not burdened by it. A positive attitude of pupils to activities in progress is essential, since motivation, as well as interest in other activities or learning itself, depend on it.

\section{Attitudes}

The substance of people's existence is thinking. It is undoubtedly the highest product of human evolution. However, it is impossible to mediate the acquired and summarised knowledge of mankind to pupils in a comprehensive manner. They would not be able to absorb a vast amount of knowledge (corresponding to the current level of development of different scientific disciplines), as this represents in most of the cases very abstract knowledge. For this reason, learning contents have to be selected to such extent that they account for a representative choice of knowledge. One of the efficient ways of such a choice can be the analysis of pupils' attitudes to different topics in the educational process.

Many authors deal with theoretical definition of attitudes, the latest of which are, for example, Adesina, \& Akinbobola (2005), Prokop, Tuncer, \& Chudá (2007), Broggy, \& McClleland, (2008), Kubiatko, \& Švandová (2012), Rusek (2013), Kubiatko, \& Rovňanová (2017) and Hitková (2017). On the one hand, authors use in most cases the definition from Nákonečný (1998) who defines the term attitude as an evaluation mechanism/opinion formation. Positive opinion that represents a positive attitude relates to

\footnotetext{
${ }^{1}$ Constantine the Philosopher University in Nitra, Faculty of Education, Department of Pedagogy, Nitra, Slovakia, rebeka.stefania.kolenakova@ukf.sk

${ }^{2}$ Constantine the Philosopher University in Nitra, Faculty of Education, Department of Pedagogy, Nitra, Slovakia,nkozarova@ukf.sk
} 
a great extent to an acquired motive reflected in the relationship between an individual and a certain phenomenon or activity (Č́a and Mareš, 2001). Attitude is similarly defined in The Pedagogical Dictionary (Průcha et al. 2009), as an evaluation mechanism that an individual has applied to their immediate surroundings (world), other subjects and himself/herself. Attitude is acquired through spontaneous learning in a family or any other social environment. On the other hand, The Psychological Dictionary (Hartl and Hartlová, 2010) defines attitude as evaluating relationship expressing the tendency to react towards situations, persons, objects and the subject itself in a certain way. Attitudes predetermine understanding, knowledge, feeling and thinking, they are an integral part of personality. Knowledge, skills and attitudes are acquired throughout life through education and various social impacts. Attitudes are relatively enduring and include cognitive, affective and behavioural component. We can measure them quantitatively by using scales or content analysis in relation to value hierarchy. Hewston and Stroebe (2001) agree with this statement and explain that every attitude contains three components (cognitive, affective and conative). The mentioned components are mostly in balance, but it can happen that one of them becomes more dominant. The cognitive component involves a person's belief and knowledge about an attitude object. The affective component involves a relation to the attitude object through person's feelings (Harkabusová, 2014). It defines attitude intensity and is related to the personality of an individual. For example, prejudices belong to strongly accentuated attitudes (Nákonečný, 2009). The behavioural component represents behaviour in compliance with acquired knowledge. The scope of knowledge, feeling and behaviour can be different within an attitude, but all components are interconnected and affect performance (Harkabusová, 2014).

Attitudes always have a function: utilitarianism, knowledge, value-expressision, and ego-defensive. Every function has respective importance for an individual and the relationship to values is reflected in them - on the basis of previous experience (Katz, 1960).

Attitude is a system of interconnected opinions, feelings and tendencies to act. Based on the knowledge of individual's attitudes to specific matter, it is possible to anticipate and at the same time regulate the behaviour towards this matter or object (Krech et al., 1968). In view of the above-mentioned information, attitudes express the evaluation relationship, emphasise what an individual considers important, what draws his/her attention, and what he/she remembers. That is why in this context attitudes are involved in information processing as important determinants (Nakonečný, 2009).

The attitude of an individual to learning, and ultimately also to a specific school subject or school teaching, can be influenced by several factors including talent, learning motivation, family, classmates, parenting style, teaching methods, teachers' behaviour towards pupils or overall class climate. Negative or positive attitudes do not necessarily represent the output from school or school system, but they are also the result of influence by family, upbringing, surroundings, media or maintained lifestyle (Kolesár and Herich, 2010).

\section{Mental maps in the learning process}

Characteristic for the term human learning is the process of development and change in knowledge, skills and attitudes. This process is reflected in the change in progress and results of activities of an individual, in performance, behaviour, survival, and is influenced by experience with the environment. It is a process of motivation, activisation, facilitation, guidance and influence on learning (Švec, 1995). The learning process falls between cognitive processes by means of which a pupil is further developed. Cognitive processes are an inseparable part of learning performance and personal development of pupils. These processes are among the most important mechanisms responsible for our learning. They are defined as a complex of psychological abilities inevitable for efficient use of knowledge for activities. In addition to learning, this complex of psychological abilities includes many other mental, cognitive operations (Kovalčikova and Ropovník, 2012).

In order to record pieces of knowledge while learning, individuals have used different visual techniques for many years and centuries. A mental map is also one form of graphical representation of knowledge. Mental maps can be used in different areas and have different forms, they can be used for planning in engineering or other industries, but also in education and teaching. Mental mapping is currently used in education as one of the activating teaching methods to develop imagination, thinking, memory, learning, to increase a pupil's motivation, and facilitate the educational process in general. 
Concept mapping can be found in the scientific literature dedicated to this matter under various titles: cognitive maps, mental maps, concept maps, mind concepts, spider mapping, network diagrams, knowledge maps, thought maps, graphical representations, structured overviews, semantic maps, or cluster arrangements.

Bendl and Voňková (2010) pointed out that almost no attention is paid to the methodology of usage and working with maps in educational process. It can also be stated that awareness of mapping is relatively low in our country. Mental mapping in scientific literature is mostly described as process-oriented teaching that does not only represent acquisition of knowledge, but also conceptually and systematically focuses on means of its acquisition. The constructivist concept of teaching is a determining factor when using concept mapping in different phases of a lesson plan. If pupils are systematically prepared for construction of their knowledge, they will structure different aspects of potential map content right during a teacher's presentation.

By the analysis of relevant literary sources, we characterise mental mapping as the creation of comprehensive diagrams of structural relations. It is an organisation of logical structure of certain pieces of knowledge, creation of causal, mutual or final relationship levels between the whole and its structural parts within teaching (thoughts, concepts, hypotheses, principles). The mental map as a mind concept is considered a crowning achievement of thinking. A map is stored in memory as a structure, in which audio and visual data about specific information together with models of efficient action are accumulated.

The mapping technique is based on the assumption that the human brain stores new information through keywords and images.

Mental mapping is a natural technique (rooted in the human thinking model) for information/knowledge organisation and visualisation of a data complex, and their mutual interactions. Mental mapping in the educational process provides new possibilities for education. With this technique, we can view learning content holistically and also analytically, it brings an innovative perspective of learning content and its structure or systematization. Mapping in educational practice can help the teacher and pupil, and their interaction.

The understanding and interpretation of a concept map is a difficult and active process with relational character, as the pupil identifies his/her own knowledge structure and key elements of the learning content. New forms of understanding are gradually achieved by connecting information with previously created functional networks of knowledge. Mental mapping is considered a useful technique that helps to make learning more efficient and to categorise acquired information into logical relationships (between concepts, thoughts, links, associations) which are structured, analysed, synthesised and generalised.

The teacher has two options when starting work with a mental map - he/she can assign pupils the task and they have to write out all the familiar words from the learning content (in this way the teacher can recognise terms considered to be primary and secondary) or the teacher can define words that should be used in the map and arranged the structure himself/herself. Graphical representations through mental maps have positive effects on cognitive processes, improve learning, but require more activity from the learner. They facilitate and streamline pupils' work - especially of individuals with problematic verbal expression. In this way, pupils have to understand their knowledge, analyse, hierarchise and organise it logically which prevents mechanical knowledge acquisition. Through mental mapping, pupils have an overview of the learning content and the cooperation in learning is strengthened by comparing between pupils and in addition, critical thinking is also significantly developed (Gunišová and Kozárová, 2016).

Particular attention to the matter of the impact of mental mapping on pupils' attitudes to learning was given by, for example, Broggy and McClleland (2008) who focused on the specific subject (physics) in their study. The main results of the study showed that university students' attitudes to physics improved after working with mental maps. Luchembe et al. (2014) in their research experiment came to the conclusion that mental mapping is a better teaching method than worksheets, since learning with mental maps is more meaningful. The study has proven in another method of an interview that pupils used mental maps for revision and comparison of the new information to the old one. Pupils also stated that they had a positive attitude to mental maps and are planning to use them for other subjects as well. 
We can observe that several experts have dealt with pupils' attitudes to learning. However, we believe that only few authors to almost none looked into pupils' attitudes to learning in primary education. That is where we see a space for our research investigation. We focused on how working with a mental map in the educational process affects pupils' attitudes to learning in primary education.

\section{Methods}

The main aim of the present study was to identify the impact of mental mapping on attitudes of primary school pupils to the learning process. The mentioned research objective has established the following relational research problem: In the educational process, what is the impact of working with mental maps on the attitudes of primary school pupils to learning? The research problem established a hypothesis that has been verified through research investigation.

H1: We assume that pupils whose teacher has regularly applied mental maps in the educational process have a more positive attitude to learning than pupils whose teacher did not apply mental maps regularly.

In the research investigation, we used a scale questionnaire with 11 items, the goal of which was to identify the subjective opinions and attitudes of pupils to working with mental maps, learning itself and education through mental maps. The questionnaire was completed by pupils working with mental maps regularly and pupils who know mental maps, but do not work with them regularly. These pupils see them just as an activity in a workbook or textbook. The employed questionnaire is not standardized, but it was specifically created for the needs of this study and is intended for pupils in primary education in the Slovak republic who have at least known mental maps before and can read and write. For the purpose of this study, the focus was on items defining views and opinions on learning and education through mental mapping. We have also conducted interviews with teachers on the attitudes of pupils to learning through different methods including mental mapping.

The selection of the research sample was determined by several factors. There were 182 respondents pupils of the third and fourth grade that were adequately accustomed to the school environment. Learning content in the selected grades is more comprehensive. Their ability to express themselves through writing and visualisations changes as well. For our research sample, we selected pupils of the third and fourth grade who have already worked with mental maps in the educational process. The survey was conducted in seven primary schools in the Nitra, Trenčín and Banská Bystrica region in the Slovak Republic. There were 182 respondents in the survey who answered eleven questions, of which 101 pupils have worked with mental maps regularly and 81 pupils have worked with mental maps irregularly or not at all. We compared the answers of these two groups of pupils in the charts below.

\section{Results}

The obtained data has been processed and analysed using Microsoft Excel. The assessment of the questionnaire is graphic, and the results were analysed based on the answers of the respondents to individual questions as presented in the following charts.

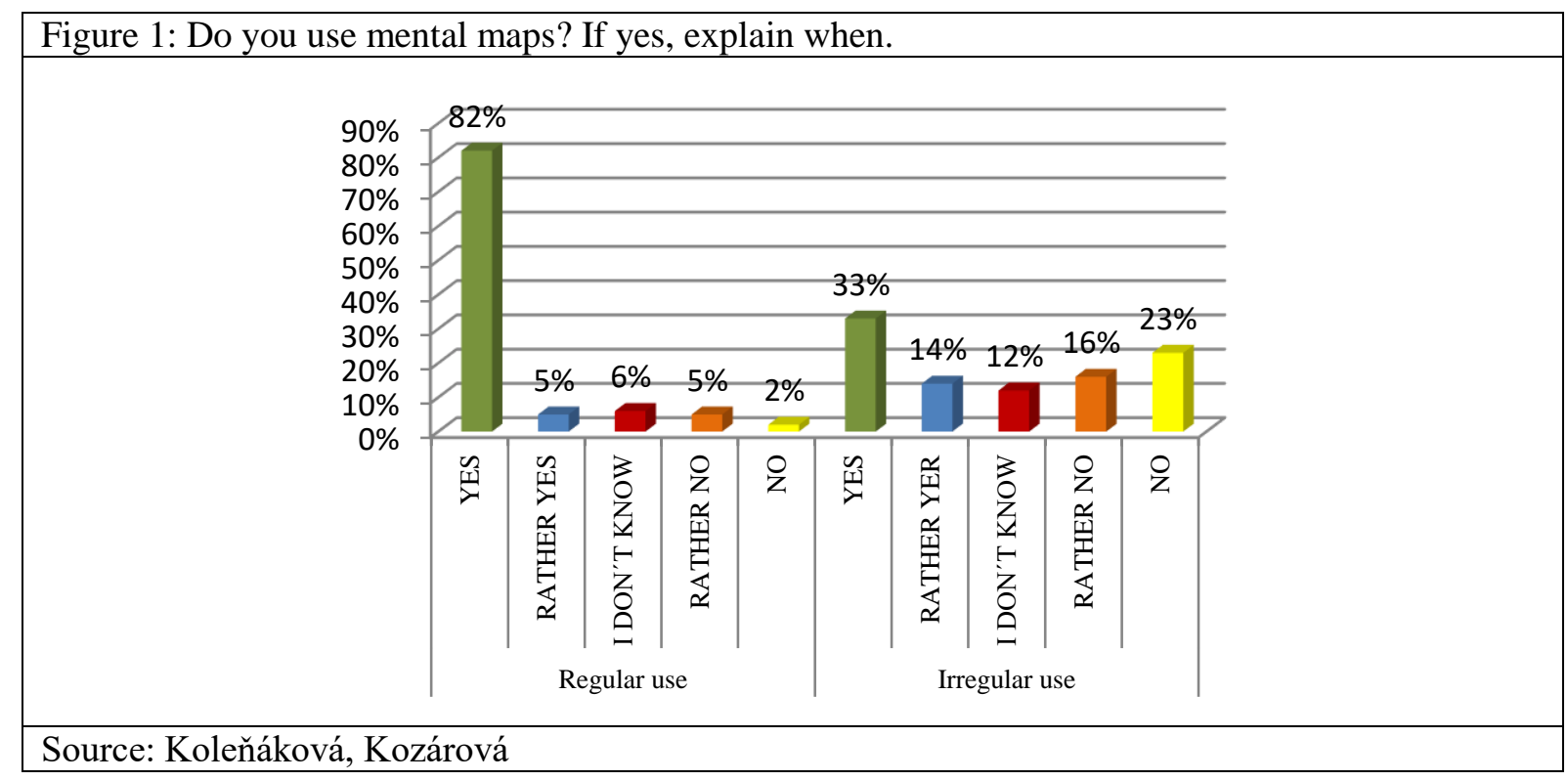


We can see in Chart 1 that $82 \%$ of surveyed pupils answered that they work with mental maps regularly. Only 5\% were also in favour of this answer, while the remaining $11 \%$ responded that they do not know mental maps or cannot work with them. In the group of pupils who do not work with mental maps regularly, only $33 \%$ responded that they use mental maps, the remaining $12 \%$ could not respond to this question and $23 \%$ responded that they do not use mental maps while the remaining $16 \%$ were also in favour of this answer. Pupils who work with mental maps stated that they use mental maps mostly during lessons of science, national history, the Slovak language, creative reading and writing. Some of them wrote that they use them for revision, home learning or doing homework, but did not specify a particular task.

Figure 2: Do you remember more when you make a mental map from learning content or when you make one during lesson?

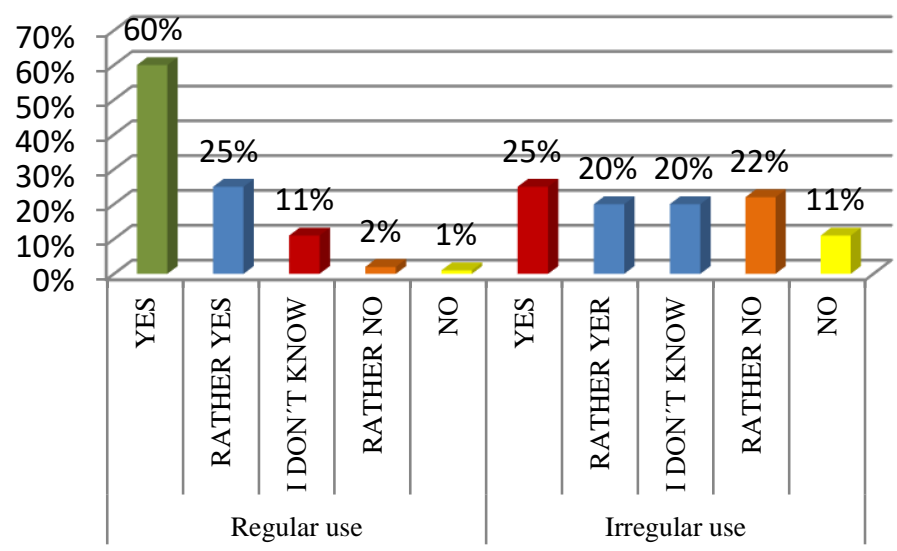

\section{Source: Koleňáková, Kozárová}

We can see in Chart 2 that $60 \%$ of surveyed pupils who work with mental maps regularly thought that they can remember more with mental maps. A particularly pleasing finding is the fact that $25 \%$ were also in favour of this answer. The remaining $14 \%$ responded that they cannot choose which form of work with mental maps they prefer to remember more. In the group of pupils who do not work with mental maps regularly or at all, only $25 \%$ responded that they can remember more with mental maps and $20 \%$ were in favour of this answer, another $20 \%$ could not answer this question, $11 \%$ responded that they cannot remember more with mental maps. The remaining $22 \%$ were also in favour of this answer. The chart shows that pupils working with mental maps are aware of the benefits of working with mental maps and able to remember more of the learning content made into a mental map.

\begin{tabular}{|l|l|l|l|l|l|l|l|l|}
\hline Figure 3: Is it fun to learn at school? \\
\hline \\
\hline
\end{tabular}

We can see in Chart 3 that $63 \%$ of surveyed pupils who work with mental maps regularly perceived and thought of learning at school as fun and another $22 \%$ were also inclined to this answer, the remaining 
$14 \%$ of pupils responded that they do not know or that learning at school is no fun at all. In the group of pupils who do not work with mental maps regularly or at all, $40 \%$ responded that learning at school is fun and only another $15 \%$ were in favour of this answer. 10\% selected the answer I do not know and for $20 \%$ of respondents stated that learning is no fun, and the remaining $15 \%$ were also in favour of this answer. The chart shows that pupils working with mental maps more regularly feel much better about learning at school than pupils who do not use mental maps often or at all.

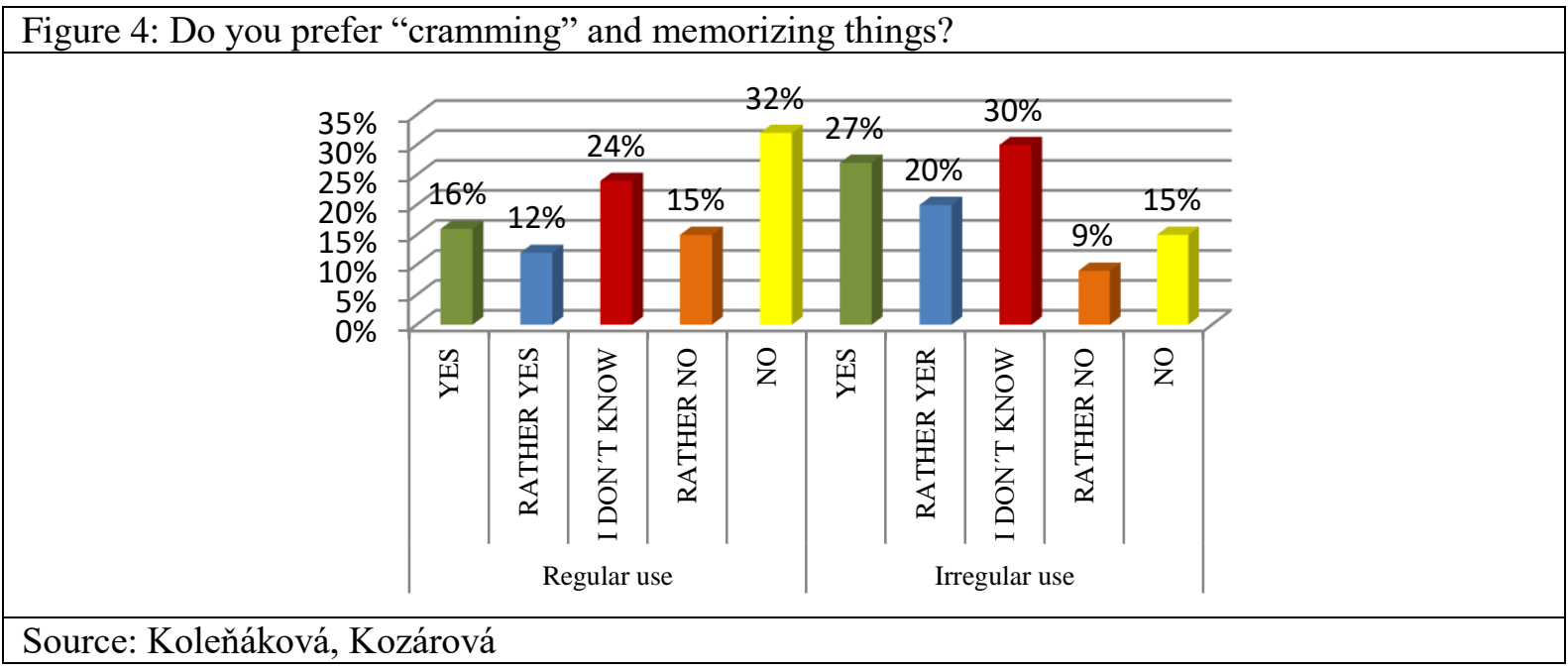

Chart 4 with pupils' answers shows that only $16 \%$ of surveyed pupils who have worked with mental maps regularly liked "cramming" and $12 \%$ were inclined to this answer. We consider it a success that up to $32 \%$ pupils responded that they do not like "cramming", and the remaining $15 \%$ were in favour of this answer. In the group of pupils who do not work with mental maps regularly or at all, $27 \%$ responded that they liked "cramming" while another $20 \%$ were inclined to this answer. Another $30 \%$ did not know the answer to this question, $15 \%$ responded that they do not like "cramming". This chart clearly shows that pupils who use mental maps regularly do not like "cramming" but prefer working with mental maps - as they need to understand the content they are learning. By contrast, the second group of pupils who do not work with mental maps regularly chose the answer of memorizing things which can be a consequence of the fact that they do not necessarily know any different ways of learning something

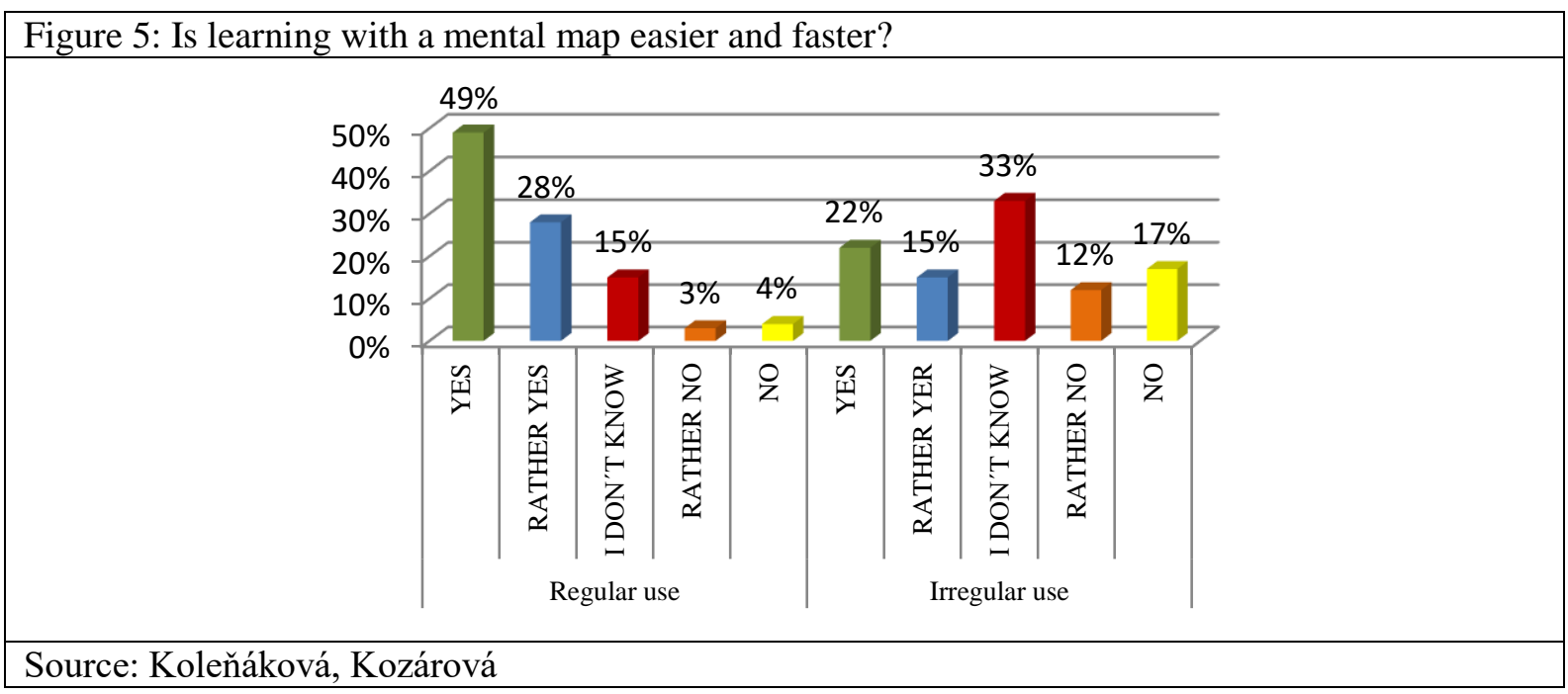

Chart 5 shows that $49 \%$ of the surveyed pupils who work with mental maps regularly thought that they learn better and faster thanks to working with a mental map. $28 \%$ respondents were inclined to this answer, too. Rather surprisingly is that only $4 \%$ pupils responded that they do not learn with a mental map better and faster, and the remaining $3 \%$ were inclined to this answer. In the group of pupils who do not work with mental maps regularly, $22 \%$ responded that they learn with a mental map better and faster and another $15 \%$ were in favour of this answer. Another $17 \%$ of respondents answered that they do not 
learn with a mental map better and faster and the remaining $12 \%$ were also in favour of this answer. The pupils who responded that they do not learn with a mental map better and faster, wrote that they prefer to memorize everything from notes in an exercise book. At the same time, they realise that this kind of learning is mechanical and without deeper understanding.

Based on the conducted and evaluated questionnaire survey, we can conclude that the hypothesis H1 was confirmed. On the one hand, we have found out that thanks to mental mapping in educational process pupils gain a deeper insight into the learning content and participate in lessons more. They perceive learning as fun and relax and are not afraid of it. On the other hand, pupils who do not use mental maps are often loath to go to school, do not want to participate in any activities, and show no interest or inner motivation to learn.

\section{Conclusion}

There are many efficient and useful education methods we know from the literature that lead to the comprehensive personal development of pupils. To a great extent, learning plays an important role in this development. We deem it important that the efficiency of teaching is increased through innovations, modifications and application of different learning strategies brought to the educational process.

Our aspiration in the present paper was to highlight the efficient learning and teaching method through mental mapping (and the importance of its application in the educational process). We believe that it is necessary to constantly remind teachers in educational practice of the benefits of this method. The role of a teacher in the educational process is to provide pupils with a good feeling and the motivation for learning and personal development. If a pupil is to improve and make his/her learning and information processing more efficient, they have to be able to choose an appropriate strategy for the given learning situation.

If we want to make teaching more efficient, it is important to make learning active and efficient. The question is, if it is even possible. Can we affect learning efficiency by working with different educational strategies? Do teachers sufficiently emphasise the development of different cognitive functions of pupils?

The study emphasizes more positive attitudes and perceptions of learning by primary school pupils. Mental mapping is one of the appropriate learning methods used by pupils in primary education. The application of mental maps to the learning process does not only make education more efficient, but thanks to their activating function pupils become active participants in the modification of their knowledge systems. Mapping also helps pupils with faster understanding and linking of knowledge that can be applied in practice. As proven in the survey, the usage of mental maps changes the perception and attitude towards learning and the educational process.

The strategy of mental mapping can also develop critical and creative thinking of pupils. Although this method requires patience and understanding in the beginning, it is ultimately an appropriate way of meaningful learning for pupils.

\section{Acknowledgments}

This study has been written under the project: APVV-15-0368 Practice in the centre of the subject field didactics, subject field didactics in the centre of preparation for practice.

\section{References}

Adesina, A. O., \& Akinbobola, A. O. (2005). The attitude of students toward part-time degree programme of the fakulty of education, Obafemi Awolowo University, Ile-Ife. Journal of Research of Education, 2(1), 1-4.

Bendl, S., \& Voňková, H. (2010). Využití pojmových map ve výuce pedagogiky [Application of Concept Maps in Pedagogy Teaching]. Pedagogická orientace, 20(1), 16-38.

Broggy, J., \& McClleland, G. (2008). Undergraduate students' attitudes towards physics after a concept mapping experience. Concept Mapping: Connecting Educators. Proc. of the Third Int. Conference on Concept Mapping Tallinn, Estonia \&

Helsinki, Finland. Available at http://cmc.ihmc.us/cmc2008papers/cmc2008-p075.pdf

Čáp, J., \& Mareš, J. (2001). Psychologie pro učitele [Psychology for Teachers]. Praha: Portál.

Gunišová, D., \& Kozárová, N. (2016). Pojmové mapy v teórii a praxi [The Theory and Practice of Concept Maps]. Nitra:

ForPress Nitrianské tlačiarne s.r.o.

Harkabusová, E. (2014). Rozvoj osobnosti žiaka hodnotením učebnej činnosti a výkonu [The Development of Pupil's

Personality by Evaluation of Educational Activity and Performance]. Bratislava: Metodicko-pedagogické centrum.

Hartl, P., \& Hartlová, H. (2010). Vel'ký psychologický slovník [The Great Dictionary of Psychology]. Praha: Portál s.r.o. 
Hewstone, M., \& Stroebe, W. (2006). Sociálni psychologie [Social Psychology]. Praha: Portál.

Hitková, P. (2017). Zlepšovanie postoja žiakov k angličtine ako vyučovaciemu predmetu pomocou naratívnych techník a autentických kníh [Improving Pupils’Attitude toward English as a School Subject by Narrative Techniques and Authentic Books]. Scientia et Eruditio, 7(3), 67-84. Available at pdf.truni.sk/see/download?see-2017-03-07-hitkova.pdf

Katz, D. (1960). The functional approach to the study of attidues. Public Opinion Quarterly, 24, 163-204.

Kolesár, J., \& Henrich, J., (2010). Vybrané aspekty vzt’ahu žiakov k súčasnej škole (1). (Rozdiely v postojoch žiakov neštátnych a štátnych škôl) [Selected aspects of pupils' relationship toward contemporary schools (1). (Differences in attitudes of non-state and state school pupils)]. Ústav informácii a prognóz školstva [The Institute of Information and Prognoses of Education]. Available at http://www.cvtisr.sk/buxus/docs/JH/vzs-zriadovatel.pdf

Kovalčíková, I., \& Ropovník, I. (2012). Exekutívne fungovanie ako predpoklad schopnosti učit' sa [Executive Functioning as a Prerequisite of Learning Ability]. Pedagogické rozhl'ady, 21(5), 1-5.

Krech, D., Crutchfield, R.S., \& Ballachey, E. L. (1968). Človek v spoločnosti [Human in Society]. Bratislava: SAV.

Kubiatko, M., \& Rovňanová, L. (2017). Osobnost' učitel’a ako jeden z možných faktorov vnímania vyučovacieho predmetu: na príklade prírodopisu [Teacher's Personality as one of the Factors of School Subject Perception]. Lifelong Learning celoživotní vzdelávání, 7(1),74-91. Available at http://lifelonglearning.mendelu.cz/wcd/w-reklifelong/l11701/lifele2017070174.pdf

Kubiatko, M., Švandová, K., Šibor, J., \& Škoda, J. (2012). Vnímání chemie žáky druhého stupně základních škol [Perception of Chemistry by Secondary School Pupils]. Pedagogická orientace, 22(1) 82-96.

Luchembe, D., Chinyama, K., \& Jumbe, J. (2014). The Effect of Using Concept Mapping on Student's Attitude and Achievement When Learning the Physics Topic of Circular and Rotational Motion. European J of Physics Education, 5(4), 10-29. Available at https://files.eric.ed.gov/fulltext/EJ1068159.pdf

Nákonečný, M. (1998). Základy psychológie [Introduction to Psychology]. Praha: Academia.

Nákonečný, M. (2009). Sociální psychologie [Social Psychology]. Praha: Academia.

Prokop, P., Tuncer, G., \& Chudá, J. (2007). Slovakian students' attitudes toward biology. Eurasia Journal of Mathematics, Science \& Technology Education, 3(4), 287-295.

Průcha, J., Walterová, E., \& Mareš, J. (2009). Pedagogický slovník [Dictionary of Pedagogy]. Praha: Portál.

Rusek, M. (2013). Vliv výuky na postoje žáků SOŠ k chemii [Impact of Education on Vocational School Students' Attitudes toward Chemistry]. Scientia in educatione, 4(1), 33-47.

Švec, Š. (1995). Základné pojmy v pedagogike a andragogike [Basic Terms in Pedagogy and Andragogy]. Bratislava: IRIS. 